ним елементом в Україні та наданий можливий варіант подолання даної проблеми.

Ключові слова: спадкування, спадкодавець, спадкоємець, спадкування за законом, спадкування за заповітом, колізія, іноземний елемент, міжнародне приватне право, спадкові правовідносини.

Korniew Y. V., Koval I. O. Features of legal regulation of hereditary relations in international private law In many countries, the rules governing inheritance relations are reflected in the Civil Codes. For example, the German Civil Code of 1896 contains a book V «Ancestral Law»; The French Civil Code of 1804 contains the relevant provisions concerning inheritance in Book III «On Different Methods of Acquiring the Right to Own Property», namely Titles I «On inheritance» and Title II «On donation between living and bequeathed».

Also, in addition to titles, codes and statutes, the inheritance relationship may be governed by specially adopted separate laws (Spain). It is not impossible not to notice that, as a result of the reception of Roman law inheritance law, especially in continental Europe, is characterized by the common rice. The system of inheritance in the countries of the Anglo-American legal family is different from this order, which is primarily due to the leading role of the judicial precedent in these states.

A foreign element during inheritance is manifested in the fact that abroad there is an inherited property or a successor or heir (the latter may have the citizenship of another country). In such situations, the parties to the hereditary legal relationship, the notary and the court do not have enough knowledge of the material rules of inheritance that operate in individual countries, they must also take into account the rules of law applicable to hereditary relationships, complicated by a foreign element.

In the law of Ukraine for the regulation of hereditary relations with a foreign element, the preference is given to the collisional method, which is a method of indirect regulation of these relations and consists in choosing the rule of law, if they regulate these relations, «seek» the rule of law of two or more states

The place of conflict rules in the system of sources of legal regulation of inheritance by law in private international law is investigated, their importance for the regulation of hereditary relations with a foreign element. The legal regulation of hereditary relations in different countries is considered. The process of inheritance under Ukrainian legislation is highlighted and a comparative analysis has been made with the legislation of some countries. The problems of legal regulation of hereditary relations with a foreign element in Ukraine are considered and a possible variant of overcoming this problem is given.

Key words: inheritance, successor, heir, inheritance by law, inheritance by will, conflict, foreign element, international private law, inheritance legal relationship.

DOI: 10.33.66.3/2524-017X-2019-10-308-312

УДК 342.7

Тетяна Анатолївна Костецька, стариий науковий співробітник Інституту держави і права ім. В. М. Корецького

НАН Украӥни, кандидат юридичних наук, доиент

\title{
ДО ПИТАННЯ ПРО ДЕРЖАВНИЙ КОНТРОЛЬ ЗА ДОТРИМАННЯМ ІНФОРМАЦЙННОГО ЗАКОНОДАВСТВА: ПОНЯТТЯ, ОКРЕМІ ВИДИ І ФОРМИ
}

Постановка проблеми. Незважаючи на наявність значного відповідного потенціалу, нинішній стан розвитку України характеризується, зокрема, існуванням суттєвих проблем з формування та реалізації ефективної державної політики у сфері розвитку інформаційного суспільства, в якій, як визначено разом із іншими чинниками, відсутній план дій щодо реалізації національної стратегії щодо такого розвитку; не подолано цифрову нерівність у доступі громадян України до електронних комунікацій та інформаційних ресурсів, повільно зростає рівень комп'ютерної грамотності населення; має місце низький рівень впровадження та використання можливостей інформаційнокомунікаційних технологій у багатьох сферах [1 ].

Зростаюча роль у комплексному вирішенні поставлених на державному рівні завдань, виходячи із національних інтересів та забезпечуючи баланс інтересів особистості, держави, суспільства зага- 
лом, належить ефективній контрольній діяльності органів публічної влади, встановленню реального контролю за функціонуванням суб' єктів інформаційної діяльності, дотриманням вимог чинного законодавства як важливого чинника вдосконалення соціального управління в Україні.

Окреслене набуває якісно нового значення у світлі пошуку найбільш ефективних шляхів, суттєвих форм та методів, дієвих механізмів у вирішенні завдань і проблем, що стоять перед вітчизняними органами публічної влади в сучасних умовах, прийняття зважених владно-управлінських рішень, впровадження контролю громадянського суспільства тощо.

Загалом контроль в інформаційній сфері є явищем багатогранним і багатоаспектним. Це обумовлює різні характеристики, не зовсім точні уявлення його суті, поняття тощо. Отже, юридичні аспекти в даному випадку є надзвичайно широкими і потребують поглибленого комплексного дослідження [2, с. 404-408]. Додамо, що в спеціальній літературі такий контроль, хоча й без трактування самого поняття, узагальнено іноді називають «інформаційний контроль», «інфокомунікаційний контроль».

Оскільки серед різновидів публічного контролю в інформаційній сфері вагоме місце належить державному контролю, параметри якого на сьогодні моделюють нагальні завдання інформаційної діяльності держави, іiї інформаційної функції, окремі його аспекти стали предметом цієї роботи. Здійснення державного і громадського контролю за додержанням законодавства про інформацію законодавчо закріплена гарантія права на інформацію в Україні (ст. 6 Закону України «Про інформацію») - є одним із пріоритетних напрямів контролю в інформаційній сфері.

Як свідчить, аналіз останніх досліджень та публікацій, спеціальному висвітленню питань контролю, контрольної діяльності в інформаційній сфері присвячено певне коло переважно адміністративно-правових досліджень та наукових праць фахівців інформаційного права з проблем державної інформаційної політики як такої, або окремих ііі напрямків. Заслуговують на увагу, зокрема, розробки вітчизняних вчених І. Арістової, К. Бєлякова, В. Брижка, О. Довганя, Б. Кормича, А. Марущака, Н. Мороз, Ю. Мосенко, М. Ніколайчука, Н. Новицької, О. Олійника, В. Пилипчука та ін.

Теоретико-методологічною основою дослідження проблем у межах окресленої тематики можна назвати також розробки присвячені правовим питанням контролю у державному управлінні, в тому числі у сфері державного управління національними інформаційними ресурсами, проблемам парламентського контролю, таких вітчизняних дослідників, як: В. Авер'янов, О. Андрійко, Ю. Барабаш, В. Дрешпак, А. Колодій, О. Майданник, Г. Поцепцов, О. Соснін, В. Шамрай та ін.

Своєю чергою, інститут досліджуваного контролю має конституційну природу, хоча безпосередньо в тексті Конституції України дотичні терміни не вживаються. В даному випадку конституційні норми найвищої юридичної сили $є$ відправними засадами для регулювання інформаційних відносин загалом, досить вагомої матерії конституційної уваги, включно з, якщо так можна назвати, інформаційно-контрольними відносинами.

Таким чином, проблематика контролю в інформаційній сфері, в тому числі державного контролю за дотриманням інформаційного законодавства належить, поза всяким сумнівом, до предмета досліджень науки конституційного права.

Однак слід констатувати, що конституційно-правові проблеми цієї сфери відносин, які могли би стати фундаментальними для всіх галузевих розробок, у сучасній юридичній науці на сьогодні не отримали комплексного і системного висвітлення. Окремих аспектів проблематики у різні періоди становлення і розвитку інформаційних відносин, здійснення державної інформаційної політики торкалися такі, наприклад, фахівці, як: Н. В. Кушакова, О. В. Нестеренко, В. Ф. Погорілко, В. О. Серьогін, О. В. Скрипнюк, І. М. Сопілко та ін.

Комплексні конституційно-правові монографічні розробки відповідних питань, зокрема, присвячені проблемам здійснення державного чи парламентського контролю за додержанням законодавства щодо реалізації сукупного конституційного права на інформацію, чи законодавства у сфері доступу до інформації окремо, які б відповідали сучасним потребам, у вітчизняній юридичній науці на сьогодні відсутні.

Отже, актуальність дослідження зумовлена потребою системного наукового аналізу сутнісної характеристики, поняття, видів та форм контролю, контрольної діяльності в інформаційній сфері, що є надзвичайно динамічним явищем, а, отже, потребує відповідних динамічних реагувань 3 боку правників з врахуванням сучасних реалій та перспектив ії розвитку, стратегічних цілей розвитку українського суспільства, держави в цілому. 
Мета статті - формування наукових підходів до сутності та поняття державного контролю за дотриманням інформаційного законодавства, його видів, форм, правового забезпечення здійснення.

Основні результати дослідження. Для реалізації окресленої мети у науково-теоретичному аспекті, на наш погляд, $є$ сенс опиратися на вагомі наукові розвідки, які мають концептуальне значення щодо предмета нашого дослідження, а саме характеристики контролю як функції соціального, державного управління, як такої, що отримала найбільшого поширення в юридичній науці.

При цьому слід зважати на відсутність єдиного наукового визначення поняття державного контролю, підходу до його класифікації тощо.

Зокрема, досить поширеною $є$ точка зору, згідно з якою контроль визначається як конкретна форма діяльності (роботи) певного органу держави, що мас контрольні права і повноваження [4, c. 283], або самостійна діяльність уповноважених на те суб’єктів, спрямована на встановлення фактичних даних щодо об'єктів цього контролю з метою визначення ії відповідності/невідповідності тим правомірним оціночним критеріям, які припускають застосування адекватних одержаному результату заходів реагування в унормованому порядку [5, с. 16].

В контексті представленої проблематики слід зазначити, що в спеціальній літературі була приділена увага дослідженню поняття, змісту, форм і методів державного контролю в інформаційній сфері як складової державної інформаційної політики [6], державного контролю в галузі аудіовізуальних засобів масової інформації [7], державного контролю у сфері інформатизації [8].

Не відкидаючи значущості доробку вітчизняних правознавців у названому напрямку, припускаємо, що теоретико-методологічні підстави подібних досліджень з урахуванням національних особливостей функціонування такого соціально-правового явища, яким є інформаційна сфера, на сьогодні у правовій науці належним чином не визначені.

Як сказано раніше, державний контроль за дотриманням (додержанням) інформаційного законодавства є одним із напрямів контролю, здійснюваного в інформаційній сфері.

Як приклад. До об'єктів, зокрема, державного контролю в галузі діяльності друкованих та аудіовізуальних 3МІ фахівці відносять не тільки інформаційну, а й загальну їх господарську діяльність як суб'єктів господарювання та дотримання під час встановленого законодавства порядку здійснення, а ще, наприклад, дотримання аудіовізуальними ЗМІ вимог та умов ліцензії чи інших відповідних обов'язків, покладених на них законодавством України.

При цьому, окрім лаконічної форми відповідного контролю, інших параметрів, які б дали розуміння сутності, особливостей відповідних видів тощо, у законодавчих встановленнях не міститься.

Виходячи із аналізу норм чинного галузевого законодавства, підконтрольними об'єктами державного контролю слід вважати саму інформаційну діяльність різноманітних суб'єктів та стан інформаційної сфери як сукупного результату такої діяльності.

Враховуючи існуючі концептуальні підходи і не розвиваючи поглибленої дискусії, вважаємо, що у «діяльнісному» вимірі, як найбільш поширеному серед науковців, відповідний контроль, на нашу думку, можна розглядати як діяльність уповноважених органів публічної влади та їх посадових осіб по встановленню фактичної відповідності результатів діяльності підконтрольних суб'єктів інформаційної діяльності очікуваним цілям, перевірці шляхів і засобів досягнення цього результату на відповідність нормам чинного законодавства та прийняттю за ії результатами відповідних заходів регулятивного, охоронного характеру.

Крім того, для розуміння правової природи державного контролю в означеній сфері суспільних відносин важливе значення має його розгляд у співвідношені таких понять, як «нагляд» $\mathrm{i}$ «контроль». Чинне законодавство не містить їх чіткого розмежування в жодній предметній галузі, а в науковій літературі це питання вже тривалий період є традиційно дискусійним.

Слушною є думка, згідно з якою в інформаційній сфері ці категорії мають відмінності з огляду на встановлені законодавством функції та повноваження контролюючих органів. Погоджуючись із правомірністю подібного розмежування, відмітимо, що у названих поняттях спільним є забезпечення законності у відповідній сфері відносин, виявлення порушення вимог законодавства.

Отже, $\epsilon$ підстави розглядати їх в комплексі як контрольно-наглядову діяльність. Будучи одночасно невід'ємним правом і обов'язком відповідних уповноважених органів влади публічної влади, вона здійснюється відповідно до приписів конституційно-правових норм, забезпечує реалізацію конституційних принципів народовладдя, верховенства права і закону, розподілу державної влади тощо. Отже, мова йде про забезпечення конституційної законності у державі та суспільстві загалом. 
Правовими засобами здійснення контрольно-наглядової діяльності, застосування яких забезпечує досягнення юридичної цілі і задоволення відповідної юридичної потреби [9, с. 20], як обгрунтовують, $\epsilon$ правосвідомість, правова культура (в контексті представленої тематики - інформаційно-правова культура. - Т. К.). До спеціальних засобів відносять нормативно-правові акти, принципи права, контрольно-наглядові акти. У сукупності вони утворюють механізм правового регулювання досліджуваної діяльності. У процесі здійснення такої діяльності забезпечується, зокрема, ефективність конституційно-правового регулювання у певній сфері суспільних відносин.

3 огляду на наведені, та враховуючи інші обгрунтовані фахівцями характерні риси, під контрольно-наглядовою діяльністю в даному випадку можна розуміти спрямовану на забезпечення дотримання законодавства (законності) діяльність уповноважених (зобов'язаних) органів публічної влади по виявленню та запобіганню його порушень, виявленню недоліків у здійсненні інформаційної діяльності, створенню умов для їх вирішення, що здійснюються за допомогою спеціальних правових засобів.

Відповідно до існуючих засад, видами державного контролю в інформаційній сфері окремі фахівці називають парламентський, президентський, внутрішній адміністративний (контроль у самій системі органів виконавчої влади), судовий та прокурорський нагляд.

Для дієвої системи контролю в національній інформаційній сфері (інформаційного контролю) 3 метою забезпечення іiї поступального функціонування, розвитку, усунення існуючих негативних явищ тощо, ключове значення має поєднання зусиль всіх суб'єктів державного контролю - зокрема, органів парламентського, президентського, адміністративного, судового контролю, спеціально уповноважених на здійснення контролю і нагляду в межах наданої компетенції.

Зокрема, як різновид державного контролю, парламентський контроль прямо встановлений чинним законодавством. Наприклад, Закон України «Про доступ до публічної інформації» разом 3 іншими окремо виділяє цей контроль як правову гарантією за дотриманням права на доступ до публічної інформації (ст. 3). Зрозуміло, що в механізмі контрольної діяльності, в тому числі за режимом доступу до публічної інформації, цей контроль займає провідну роль.

Парламентський контроль, в тому числі в інформаційній сфері, є однією з найважливіших функцій Верховної Ради України, реалізується через відповідні контрольні повноваження, включаючи й ті, що встановлені щодо здійснення інших основних парламентських функцій - законодавчої, організаційної.

Відповідно до Конституції України парламент створює насамперед законодавчу основу здійснення інформаційної політики, державного регулювання та контрольної діяльності у сфері інформаційних відносин, визнаючи при цьому напрями діяльності всіх суб'єктів інформаційної діяльності, всіх органів публічної влади (державних органів, органів місцевого самоврядування), інституцій та здійснює контроль за реалізацією прийнятих нею нормативно-правових актів, перевіряє дотримання встановлених приписів усіма учасниками інформаційних правовідносин.

Виходячи із доктринального розуміння парламентського контролю, суб'єктами здійснення контрольно-наглядової діяльності у сфері досліджуваних відносин є сам парламент, його структурні органи (комітети, тимчасові слідчі, спеціальні комісії), а також органи, що здійснюють відповідну діяльність від імені Верховної Ради - зокрема, Уповноважений Верховної Ради України 3 прав людини.

Нормативно-правовий аналіз дозволяє говорити про наявність законодавчо визначеного широкого інструментарію по здійсненню парламентського контролю, в тому числі за дотриманням інформаційного законодавства. Це депутатські запити; депутатські звернення; парламентські слухання, дні Уряду України; Президента України; контрольна діяльність комітетів, тимчасових спеціальних та слідчих комісій парламенту; i, певно, діяльність Уповноваженого Верховної Ради України з прав людини та Рахункової палати тощо. Форми парламентського контролю тісно пов'язані між собою, a їх застосування $\epsilon$ чинником забезпечення ефективності контрольної діяльності.

Зокрема, комітети парламенту, як суб'єкти контрольної діяльності, наділені різноманітними правовими формами ії здійснення. Відповідно до Закону України «Про комітети Верховної Ради України» (ст.14) такими, зокрема, $\epsilon$ аналіз практики застосування законодавчих актів у діяльності державних органів, їх посадових осіб з питань, віднесених до предметів відання комітетів, підготовка та подання відповідних висновків та рекомендацій на розгляд Верховної Ради; участь ії̈ дорученням у проведенні «Дня Уряду України»; контроль за виконанням Державного бюджету Украї- 
ни в частині, що віднесена до предметів їх відання, для забезпечення доцільності, економності та ефективності використання державних коштів у порядку, встановленому законом; організація та підготовка за дорученням Верховної Ради парламентських слухань; взаємодія комітетів, наприклад, з Уповноваженим Верховної Ради України з прав людини; направлення матеріалів для відповідного реагування в межах, установлених законом, органам Верховної Ради України, державним органам, їх посадовим особам тощо.

Об’єктами контролю комітетів є, зокрема, діяльність Кабінету Міністрів України та центральних органів виконавчої влади по дотриманню вимог чинного законодавства. Вказаний напрям контролю поширюється фактично на всю діяльність органів державної публічної влади в інформаційній сфері. Серед таких об’єктів - діяльність друкованих, аудіовізуальних, електронних ЗМI, інформаційних агенств та інших суб’ єктів інформаційної діяльності.

Наприклад, законодавством передбачено, що у випадку встановлення комітетом порушення, зрозуміло, інформаційних також, прав, свобод і інтересів людини та громадянина, інтересів держави, територіальної громади, що охороняються законом, комітет може направити матеріали для відповідного реагування в межах, встановлених законом, органам Верховної Ради, державним органам чи органам місцевого самоврядування (ст. 33 названого закону).

Крім того, оскільки парламентський контроль здійснює управлінську, корегуючу, правоохоронну, інформаційну, превентивну функції, комітети мають право задіювати як контрольні й інші форми, що пов’язані із виконанням всіх функцій з предметів їх відання.

Як свідчить сучасна практика, суб’єктами такого непрямого парламентського контролю за дотриманням інформаційного законодавства здійснювався пошук вдосконалення форм і методів контрольної діяльності. Мова йде, зокрема, про діяльність Комітету з питань свободи слова і інформаційної політики Верховної Ради восьмого скликання, який з моменту свого створення визначив напрямок на принципове, кардинальне і системне вдосконалення чинного законодавства, яке відповідало б потребам життя, нормам і стандартам європейського законодавства [10].

Водночас ступінь результативності відповідної контрольної діяльності не у всіх випадках виявилася належною. Як відмічають самі члени названого Комітету, не дивлячись на позитивні результати, орган не повною мірою використовує контрольні повноваження щодо діяльності центральних органів виконавчої влади [11].

Втім, при наявних певних недоліках нормативно-правового забезпечення, практики проведення, парламентський контроль за додержанням законодавства в інформаційній сфері є одним із його основних і всеосяжних напрямів. Це потребує постійної уваги до проблем здійснення, вдосконалення цього інституту.

Загалом, проблема налагодження ефективного контролю за дотриманням законодавства в досліджуваній сфері відносин на перспективу невіддільна від подолання існуючих на сьогодні таких, на наш погляд, недоліків, як: функціональна розпорошеність здійснення контрольної діяльності між численними суб'єктами різних гілок влади; відсутність комплексного аналізу конституційноправового статусу контролюючих суб’єктів в інформаційній сфері; а також невизначеність меж предметного регулювання вітчизняного інформаційного законодавства, що безпосередньо негативно позначається на встановленні, конкретизації обсягу повноважень уповноважених суб' єктів та ефективності їх здійснення

Висновок. Вищесказане дозволяє зробити висновок, що заявлена проблематика є досить складною, багатогранною i, безумовно, потребує подальшого розроблення, наукового осмислення комплексу проблем, пов'язаних із розробкою та втіленням у життя державної інформаційної політики, становленням в Україні інформаційного суспільства.

\section{Список використаних джерел}

1. Рекомендації парламентських слухань на тему: «Реформи галузі інформаційно-комунікаційних технологій та розвиток інформаційного простору України» від 31 березня 2016 р., № 1073-VIII / Відомості Верховної Ради України. - 2016. - № 17. - Ст. 191.

2. Костецька T. A. Контроль як необхідна умова функціонування інформаційної сфери, його види //Альманах права. Правова аналітика: доктринальні підходи та галузеві виміри. - Вип. 9. - К., 2018.

3. Костецька T. А. Актуальні проблеми державно-правового регулювання інформаційних відносин // Т. А. Костецька. - Часопис Київ. ун-ту права. - 2006. - Вип. 4. 
4. Сушинський О. І. Контроль у сфері публічної влади: теоретико-методологічні та організаційно-правові аспекти : моногр. / О. І. Сушинський. - Л. : ЛРІДУ УАДУ, 2002.

5. Шестак В. С. Державний контроль в сучасній Україні (теоретико-правові питання) : моногр. / В.С.Шестак. Х. : Основа, 2003.

6. Мосенко Ю. О. Державна інформаційна політика України: організаційно-правові аспекти здійснення : автореф. дис. ... канд. юрид. наук / Ю. О.Мосенко. - К., 2011. - 20 с.

7. Вознесенська О. А. Правові засади державного регулювання в галузі аудіовізуальних засобів масової інформації : автореф. дис. .... канд. юрид.наук /О. А. Вознесенська. - К. : 2014. - 20 с.

8. Мороз Н. С. Аміністративно-правове забезпечення державного контролю у сфері інформатизації : автореф. дис. .... канд. юрид.наук. - К., 2017. -20 с.

9. Пашук T. Теорія юридичних засобів: концептуально-методологічний аспект /Проблема державотворення і захисту прав людини в Україні. Матер. наук-практ.конф. (лютий, 2005). - Л., 2005.

10. Звіт про виконану роботу Комітетом Верховної Ради України з питань свободи слова та інформаційної політики за першу сесію восьмого скликання (грудень 2014 р. - січень 2015 р.) [Електронний ресурс]. - Peжим доступу : http://komsvobslova.rada.gov.ua/news/Dialnist/Vidviduvannia/zvit/73047.html

11. Ocmana C. Україна перейшла на цифру. Моніторинг роботи Комітету ВРУ з питань свободи слова та інформаційної політики у другому півріччі 2018 р. // [Електронний ресурс]. - Режим доступу : https://detector. media/infospace/article/143819/2018-12-31-ukraina-pereishla-na-tsifru-monitoring-roboti-komitetu-svobodi-slovaza-druge-pivrichchya-2018-go/

\section{References}

1. Rekomendatsii parlamentskykh slukhan na temu: «Reformy haluzi informatsiino-komunikatsiinykh tekhnolohii ta rozvytok informatsiinoho prostoru Ukrainy» vid 31 bereznia 2016 r., № 1073-VIII / Vidomosti Verkhovnoi Rady. 2016. № 17. St.191. (ukr)

2. Kostetska T. A. Kontrol yak neobkhidna umova funktsionuvannia informatsiinoi sfery, yoho vydy. Almanakh prava. Pravova analityka: doktrynalni pidkhody ta haluzevi vymiry. Vyp.9. K., 2018. S.404-409. (ukr)

3. Kostetska T. A. Kontrol yak neobkhidna umova funktsionuvannia informatsiinoi sfery, yoho vydy //Almanakh prava. Pravova analityka: doktrynalni pidkhody ta haluzevi vymiry. Vyp.9. - K., 2018.

4. Sushynskyi O. I. Kontrol u sferi publichnoi vlady: teoretyko-metodolohichni ta orhanizatsiino-pravovi aspekty : monohrafiia / O. I. Sushynskyi - L. : LRIDU UADU, 2002.

5. Shestak V.S. Derzhavnyi kontrol v suchasnii Ukraini (teoretyko-pravovi pytannia): monohrafiia /V. S. Shestak. - Kh.: Osnova, 2003.

6. Mosenko Yu. O. Derzhavna informatsiina polityka Ukrainy: orhanizatsiino-pravovi aspekty zdiisnennia : avtoref. dys. kand. yuryd.nauk / Yu.O. Mosenko. - K. : 2011. 20 s.

7. Voznesenska $O$. A. Pravovi zasady derzhavnoho rehuliuvannia v haluzi audiovizualnykh zasobiv masovoi informatsii : avtoref. dys. kand. yuryd.nauk/O. A. Voznesenska. K.: 2014. 20 s.

8. Moroz N. S. Aministratyvno-pravove zabezpechennia derzhavnoho kontroliu u sferi informatyzatsii: avtoref. dys. kand. yuryd.nauk. K. : 2017. 20 s.

9. Pashuk T. Teoriia yurydychnykh zasobiv: kontseptualno-metodolohichnyi aspekt /Problema derzhavotvorennia i zakhystu prav liudyny v Ukraini. Mater. nauk-prakt.konf. (liutyi, 2005). L., 2005.

10. Zvit pro vykonanu robotu Komitetom Verkhovnoi Rady Ukrainy z pytan svobody slova ta informatsiinoi polityky za pershu sesiiu vosmoho sklykannia (hruden 2014 r. - sichen 2015 r.) http://komsvobslova.rada.gov.ua/news/Dialnist/ Vidviduvannia/zvit/73047.html

11. Ostapa $S$. Ukraina pereishla na tsyfru. Monitorynh roboty Komitetu VRU z pytan svobody slova ta informatsiinoi polityky u druhomu pivrichchi 2018 r. // https://detector.media/infospace/article/143819/2018-12-31-ukrainapereishla-na-tsifru-monitoring-roboti-komitetu-svobodi-slova-za-druge-pivrichchya-2018-go/.

\section{Костецька Т. А. До питання про державний контроль за дотриманням інформаційного законо- давства: поняття, окремі види і форми}

Актуальність матеріалу статті зумовлена проблемою здійснення ефективної національної державної політики у сфері розвитку інформаційного суспільства, удосконалення контрольної діяльності органів публічної влади за функціонуванням суб'єктів інформаційної діяльності, дотриманням вимог чинного законодавства.

Підкреслюється багатогранність та багатоаспектність. контролю в інформаційній сфері та його напряму державного контролю за дотриманням інформаційного законодавства.

Вказується на недостатню теоретико-прикладну розробку юридичних аспектів окресленого явища, на відсутність в сучасній науці комплексного аналізу конституційно-правових проблем контрольної діяльності в означеній сфері суспільних відносин.

Аналізуються існуючі концептуальні підходи до визначення поняття «державний контроль в інформаційній сфері». 
Сформульовано авторське визначення відповідного поняття, а також поняття державного контролю за дотриманням інформаційного законодавства, контрольно-наглядової діяльності.

Окремо приділена увага різновиду державного контролю -парламентського контролю у відповідній сфері. Окреслюються суб'єкти, основні форми і методи здійснення контрольно-наглядової діяльності, її правові основи.

Звертається увага на шляхи удосконалення контролю за дотриманням законодавства в досліджуваній сфері відносин.

Ключові слова: інформаційна сфера, державний контроль, інформаційне законодавство, парламентський контроль.

Kostetska T. A. To the issue of the state control over the observance of information legislation: the concept, certain types and forms

The relevance of the article's material caused by the problem of implementing an effective national state policy in the field of information society development, improvement of control activity of public authorities on the functioning of subjects of information activity, observance of the requirements of the current legislation.

The versatility and multidimensionality of control in the information sphere and its direction - state control over observance of information legislation are emphasizing. The constitutional and legal nature of the investigated control is emphasizing.

In the scientific literature such control is sometimes called as «information control», «infocommunication control».

There is an insufficient theoretical and applied development of the legal aspects of the described phenomenon, the absence in modern science of a comprehensive analysis of the constitutional and legal problems of control activities in the specified sphere of public relations.

It is substantiating that methodologically, the study of these institutions should be base on existing significant developments in legal science regarding the characteristics of control as a function of social and public administration.

The existing conceptual approaches to the definition of «state control in the information sphere», its types, are analyzing.

The author's definition of appropriate concept, as well as the concept of state control over the observance of information legislation, control and supervision activities were formulated.

It is specifying that the legal nature of state control in the information sphere should be consider in the correlation of such concepts as «supervision» and «control». Based on the analysis of the legal content of these categories was substantiated that in the complex, they can be considered as the appropriate control and oversight activities. A description of the legal means of its implementation is given.

Separate attention is focuses to the kind of state control - parliamentary control in the relevant sphere. Emphasizes its leading role in the system of state control over compliance with information legislation.

The subjects, the basic forms and methods of control and supervision activity, its legal bases are outlining. Emphasizes the need for constant attention from experts to the problems of implementation, improvement of this institute.

The main directions of improvement of both state control over observance of information legislation and control in general in the investigated sphere of relations in general are outlining.

Key words: informative sphere, state control, information legislation, parliamentary control.

DOI: 10.33.66.3/2524-017X-2019-10-312-318 